\title{
IMPLEMENTASI PEMANFAATAN SOFTWARE PENULISAN LAPORAN HASIL BELAJAR SISWA SMK PADA PELAKSANAAN KURIKULUM 2013
}

\author{
Heri Retnawati \\ FMIPA, Universitas Negeri Yogyakarta \\ heri_retnawati@uny.ac.id \\ Samsul Hadi \\ Universitas Negeri Yogyakarta \\ samsul_hd@uny.ac.id \\ Ariyadi Chandra Nugraha \\ Universitas Negeri Yogyakarta \\ email@gmail.com

\section{Abstrak}

Penelitian ini bertujuan untuk mendeskripsikan implementasi penulisan laporan hasil belajar siswa SMK pada pelaksanaan Kurikulum 2013 menggunakan software penulisan rapor online. Penelitian ini merupakan studi deskriptif eksploratif, yang merupakan bagian dari penelitian pengembangan dengan menggunakan model Sharma. Data dikumpulkan dengan observasi dan angket. Partisipan kegiatan pemanfaatan software di SMK sebanyak 9 SMK baik negeri dan swasta di DI Yogyakarta, dengan melibatkan wakasek kurikulum, guru kelas, dan teknisi teknologi informasi dari tiap sekolah partisipan. Hasil penelitian menunjukkan bahwa 56\% responden menyatakan bahwa software yang dikembangkan memiliki kualitas baik dan sisanya $44 \%$ responden menyatakan bahwa bahwa software yang dikembangkan memiliki kualitas sedang. Beberapa masukan responden untuk perbaikan software yaitu (1) perlu adanya sinkronisasi sistem dengan peraturan pemerintah terbaru (2) penyempurnaan kelengkapan keterangan dalam sistem; (3) perlu adanya kerjasama dengan dinas pendidikan atau instansi terkait; dan (4) pembatasan wewenang siswa. Berdasarkan masukan-masukan tersebut dilakukan perbaikan sehingga software siap digunakan untuk membantu guru SMK di Indonesia menyusun laporan hasil belajar menggunakan Kurikulum 2013.

Kata kunci: software penulisan rapor online, Kurikulum 2013, siswa SMK

\section{IMPLEMENTATION OF THE USE OF THE LEARNING OUTCOMES REPORT WRITING SOFTWARE OF VOCATIONAL STUDENT ON CURRICULUM 2013}

\author{
Abstract
}

This study aimed to describe implementation of learning outcomes report writing of vocational students on Curriculum 2013 using the online report writing software. This research was descriptive exploratory study, which was part of the research development by using Sharma's model. Data collected by observation and questionnaire. Participants in this study involved 9 both public and private vocational school in Special Region of Yogyakarta Province, involving the vice principals of curriculum, classroom teachers, and information technology technicians from each school participants. The results showed that $56 \%$ of respondents stated that the developed software has good quality and the remaining $44 \%$ of respondents stated that the software developed has medium quality. Some respondents suggestions for improvements to the software, namely (1) the need for synchronization of the system with the newest government regulations (2) improvement of the completeness of information within the system; (3) the need for cooperation with the department of education or other related institutions; and (4) limitation the authority of the students. Based on these suggestions have been conducted improving the system so that the software was ready for use to assist vocational teachers in Indonesia to prepare the learning outcomes reports on Curriculum 2013.

Keywords: the online report writing software, Curriculum 2013, vocational students 


\section{PENDAHULUAN}

Salah satu bentuk dari upaya pemerintah untuk meningkatkan kualitas pendidikan yakni dengan mereformasi kurikulum. Pada tahun 2013 Pemerintah Indonesia melalui Kementerian Pendidikan dan Kebudayaan melakukan reformasi kurikulum yang merupakan perbaikan dari kurikulum sebelumnya. Kurikulum yang dimaksud dikenal dengan Kurikulum 2013. Kurikulum 2013 ini berbeda dibandingkan dengan kurikulum sebelumnya. Kurikulum 2013 tidak hanya fokus pada perkembangan kognitif saja, tetapi juga memperhatikan peningkatan sikap baik sikap spiritual maupun sikap sosial, serta perkembangan keterampilan peserta didik. Hal ini tercermin dari standar isi yang digunakan dalam Kurikulum 2013 (Permendikbud No. 64 Tahun 2013 tentang Standar Isi, (Mendikbud RI, 2013a)). Kedalaman isi pada Kurikulum 2013 juga berbeda, yang lebih menekankan penanaman sikap menjadi perilaku yang baik, kemampuan berpikir tingkat tinggi (higher order thinking, HOT), serta keterampilan yang diperlukan dalam menghadapi tantangan global. Demikian pula halnya dengan pelaksanaan penilaian yang sangat berbeda dengan kurikulum sebelumnya sebagaimana diatur dalam Permendikbud No. 66 Tahun 2013 (Mendikbud RI, 2013b), yang kemudian di perbarui melalui Permendikbud No. 104 Tahun 2014 (Mendikbud RI, 2014), dan kemudian diperbarui lagi melalui Permendikbud No. 23 Tahun 2016 (Mendikbud RI, 2016b).

Pelaksanaan penilaian (assessment) dalam pendidikan memiliki peranan penting, khususnya untuk mengetahui capaian dari penerapan suatu kurikulum. Dalam tataran praktis, proses penilaian dalam pendidikan memiliki fungsi untuk membantu guru dalam hal-hal penempatan siswa dalam kelompokkelompok tertentu, perbaikan metode mengajar, mengetahui kesiapan siswa baik sikap maupun mental, memberikan bimbingan dan seleksi dalam rangka menentukan jenis jurusan maupun kenaikan tingkat (Gronlund \& Linn, 1990, p. 16), menyediakan informasi yang membantu pendidik membuat keputusan untuk pendidikan yang lebih baik (Reynold, Livingstone, \& Wilson, 2010), dan juga membuat keputusan tentang kelanjutan studi dan evaluasi program (Johnson, Penny, \& Gordon, 2009). Mengingat pentingnya peranan ases- men tersebut, maka proses penilaian tersebut harus dilakukan secara menyeluruh atau yang sering disebut dengan penilaian autentik. Penilaian autentik ini merupakan prinsip dasar yang digunakan pada proses penilaian dalam Kurikulum 2013.

Penilaian autentik adalah penilaian yang membutuhkan siswa untuk menggunakan kompetensi-kompetensi yang sama atau mengkombinasikan pengetahuan, keterampilan, dan sikap yang mereka butuhkan untuk diaplikasikan dalam berbagai situasi dalam kehidupan profesional (Gulikers, Bastiaens, \& Kirschner, 2004; Rennert-Ariev, 2005; Lombardi, 2008). Penilaian autentik memiliki beberapa kelebihan diantaranya dapat mengungkap perkembangan peserta didik berdasarkan tujuan secara holistik, dan menilai kemampuan untuk "melakukan" pada ranah pengetahuan dan keterampilan (Nitko \& Brookhart, 2011, p. 254). Dengan demikian penilaian autentik dianggap lebih merepresentasikan kemampuan peserta didik yang sebenarnya, daripada penilaian yang dilakukan hanya menggunakan tes tertulis semata.

Salah satu hambatan bagi pendidik dalam pengimplementasian Kurikulum 2013 yaitu penilaian yang rumit dan perlu waktu yang lama untuk menyusun laporan (Retnawati, 2015; Retnawati, Hadi, \& Nugraha, 2016). Terkait dengan implementasi penilaian autentik pada Kurikulum 2013, ditenggarai masih perlunya perbaikan kualitas pelaksanaan penilaian autentik tersebut (Kartowagiran \& Jaedun, 2016, p. 131; Rukmana \& Mundilarto, 2016). Masih rendahnya kualitas penilaian autentik pada pelaksanaan Kurikulum 2013 ini disebabkan oleh banyak-nya komponen yang harus dinilai dan kemampuan pendidik yang dipengaruhi oleh beban kerja(Rukmana \& Mundilarto, 2016, p. 111). Merujuk pada standar isi (Permendikbud No. 64 Tahun 2013; Permendikbud No. 21 Tahun 2016 (Mendikbud RI, 2016a)), ada 4 aspek yang dinilai dalam Kurikulum 2013, yakni aspek sikap spiritual, sikap sosial, pengetahuan, dan keterampilan. Teknik penilaian setiap aspek juga berbedabeda. Penilaian aspek sikap (spiritual dan sosial) menggunakan pengamatan (observasi), penilaian antarpeserta didik, penilaian peserta didik, dan jurnal. Penilaian aspek pengetahuan dilakukan dengan ter tertulis, tes lisan, dan penugasan. Penilaian aspek keterampilan dilakukan dengan tes praktik, pro- 
yek, dan portofolio. Penilaian dilakukan untuk tiap Kompetensi Dasar (KD) dari tiap kompetensi inti dalam standar isi, dari tiap siswa dan tiap semester. Hasilnya dilaporkan dalam bentuk laporan hasil belajar (Permendikbud No. 66 Tahun 2013).

Sebelum dilaporkan, pendidik melaksanakan penskoran terlebih dahulu. Penskoran ini dilakukan dari berbagai teknik penilaian yang dilakukan, dibuat menjadi satu nilai pada tiap kompetensi dasar dan aspek penilaian. Dari tiap kompetensi dasar selama satu semester, dibuat menjadi satu nilai kembali pada tiap aspek, kemudian dideskripsikan. Nilai dan deskripsinya tersebut kemudian dilaporkan kepada orang tua peserta didik. Mengingat tiap mata pelajaran ada 4 aspek yang dinilai, satu semester ada beberapa KD, dan pada proses penilaiannya ada 10 teknik penilaian yang digunakan pendidik, proses penilaian ini menyulitkan pendidik dalam menuliskan laporan hasil belajar peserta didik.

Berdasarkan hasil studi pendahuluan terkait dengan pelaksanaan penilaian menggunakan Kurikulum 2013 di beberapa SMK di Yogyakarta, sebagian besar pendidik mengalami kesulitan dalam menyusun laporan hasil pendidikan di SMK. Kesulitan tersebut diantaranya (1) kesulitan melakukan penskoran pada tiap KD ketika penilaian dilakukan dengan menggunakan berbagai teknik, (2) kesulitan melakukan penskoran dari berbagai $\mathrm{KD}$ di tiap aspek penilaian, (3) melakukan konversi dari penilaian biasa menjadi penilaian skala 1 - 4 seperti yang disarankan oleh kurikulum, (4) terlalu lama melakukan konversi nilai pada skala $1-4$ menjadi nilai yang disajikan dengan huruf, (5) kesulitan mendeskripsikan data kuantitatif menjadi data kualitatif baik pada level KD maupun level mata pelajaran tiap aspek, dan (6) terlalu lama menyusun laporan hasil pendidikan peserta didik tiap semester sehingga waktu pendidik terlalu banyak digunakan untuk membuat laporan hasil belajar.

Mengingat masih banyaknya permasalahan terkait penilaian dan pelaporan hasil belajar, dimana sebagian besar waktu pendidik difokuskan untuk hal tersebut, sehingga mengakibatkan berkurangnya porsi untuk fokus pada persiapan dan proses pembelajaran. Dengan demikian, upaya untuk membantu guru dalam melakukan penskoran, menyusun laporan, dan menyusun deskripsi kemampuan siswa dalam laporan hasil belajar merupakan hal yang urgen untuk dilakukan. Dengan terbantunya pendidik dalam melaporkan hasil penilaian, diharapkan waktu pendidik dapat lebih diefisienkan untuk persiapan dan pelaksanaan pembelajaran, bukan hanya melakukan penilaian dan melaporkannya. Berbagai kendala tersebut sebenarnya dapat diatasi dengan memanfaatkan teknologi informasi melalui pembuatan software yang dapat digunakan secara bebas (open source) yang dapat membantu pendidik melakukan penskoran dari hasil penilaian, pelaporan dan menyusun deskripsinya.

Kendala-kendala dalam melaksanakan penilaian autentik dapat diatasi dengan menyiapkan sarana bantuan, baik itu dukungan peralatan penilaian maupun program aplikasi komputer pendukung, dan mengintegrasikannya dengan teknologi. Beberapa ahli mengemukakan bahwa perlunya integrasi teknologi dengan proses penilaian (Pellegrino \& Quellmalz, 2010; Clarke-Midura \& Dede, 2010). Bentuk penggunaan teknologi tersebut dapat berupa penggunaan jaringan komputer (Waycott et al., 2010), penggunaan e-tools (Heinrich, Milne, \& Moore, 2009), penilaian berbasis sistem online (Retnawati, 2015b), dan computer-based assessment (Kearney, Fletcher, \& Bartlett, 2002; Singleton, 2001).

Ada banyak manfaat yang diperoleh melalui penilaian menggunakan sistem penilaian online atau berbasis komputer, baik bagi siswa, guru, dan administrator. Ingintegrasian teknologi informasi dan komunikasi dan penilaian dapat dimanfaatkan untuk pengumpulan, penyimpanan, analisis, dan pelaporan informasi atau hasil penilaian (Buzzetto-More \& Alade, 2006; Nicol, 2008), dapat digunakan untuk membuat dan mempublikasikan perangkat penilaian autentik online (Mueller, 2005). Selain itu penskoran dengan menggunakan sistem komputer hasilnya reliabel (Rudner, Garcia, \& Welch, 2006). Dengan demikian pemanfaatan teknologi dalam penilaian hasil belajar memberikan banyak keuntungan dan dapat mempermudah pekerjaan pendidik dalam melakukan penilaian dan pelaporannya. Teknologi yang dimaksud salah satunya dapat diwujudkan dalam bentuk software atau sistem berbasis teknologi informasi.

Beberapa sekolah di kota besar telah mengembangkan sistem berbasis teknologi informasi untuk menulis laporan hasil belajar 
pada Kurikulum 2013. Namun sistem ini harganya mahal, sehingga belum tentu semua sekolah mampu membelinya. Terkait dengan hal ini, dikembangkannya software open source yang murah serta dapat digunakan bebas untuk semua sekolah pada umumnya, dan SMK di Indonesia pada khususnya merupakan hal yang sangat urgen. Tentu saja pengembangannya dilakukan melalui mekanisme yang ilmiah dengan memperhatikan standar penilaian yang berlaku dalam Kurikulum 2013 dan mempertimbangkan teori pengukuran dan evaluasi dalam pendidikan.

Selama tahun 2014 dan 2015, peneliti telah mengembangkan software penulisan rapor online. Penelitian ini dilakukan dengan tahapan mengidentifikasi permasalahan terkait dengan pelaksanaan penilaian dan pelaporan hasil belajar pada Kurikulum 2013 dan deskripsi kebutuhan (need assesment) terkait dengan software untuk membantu pelaporan hasil pendidikan di SMK, merumuskan software untuk membantu pendidik dalam melaporkan hasil penilaian pendidikan menggunakan Kurikulum 2013 berdasarkan hasil need assesment dan Delphi. Software tersebut bersifat open source dan menggunakan bahasa pemrograman PHP dengan basis data MySQL. Pemrograman ini relatif mudah untuk menciptakan HTML dan isi web yang dinamis dan dapat memberikan hasil optimal seperti yang diharapkan (Atkinson, 2001; (Bolboacă, Jäntschi，\& Cadariu， 2003; Harris，2004; Bulger, Greenspan, \& Wall, 2004; Schlossnagle, 2004; Valade, 2008; Lerdorf, Tatroe, \& MacIntyre, 2006; Gilmore, 2008; Gosselin, Kokoska, \& Eastebrooks, 2011; Nixon, 2015). Kelebihan bahasa pemrograman ini, selain dapat menyimpan data dalam jumlah yang besar, pencarian datanya juga lebih mudah, dapat digunakan untuk menghitung nilai total, rata-rata, dan operasi lainnya, dan dapat dibatasi siapa saja yang boleh dan tidak boleh mengakses data tertentu (Widigdo, 2003; Solichin, 2013). Data-data dalam pem-rograman ini disimpan dalam sebuah basis data (database) (Taylor, 2010, p. 9), dan disusun secara terstruktur (Paszko \& Turner, 2001, p. 136). Operasi data dalam database umumnya mengikuti pola yang sama, yaitu diawali dengan membuat sambungan dengan database server, memilih dan membuka database yang diinginkan, mengirim perintah untuk mengambil, mengubah, menghapus, mengakses hasil pengambilan data, dan mengakhiri sambungan. Hasil pemilihan data dapat disajikan dalam bentuk file serta dapat diedit. Dengan memperhatikan prosedur kerja dan sifat PHP dan MySQL ini, dapat disusun aplikasi atau software online untuk membantu guru menyusun laporan hasil pendidikan dalam Kurikulum 2013 termasuk mendeskripsikannya.

Hasil pengembangan software menggunakan bahasa pemrograman PHP tersebut berupa software penulisan rapor online. Software ini meliputi sistem pengolahan skor, pelaporan, dan pendeskripsiannya, sesuai dengan Kurikulum 2013, termasuk pula buku panduan penggunaannya sehingga dapat diaplikasikan di SMK khususnya dan sekolah di Indonesia pada umumnya. Hasil penelitian sebelumnya juga menunjukkan bahwa penggunaan sistem rapor online oleh tim IT dapat mempermudah pelaksanaan penilaian autentik Kurikulm 2013 (Sudiyanto, Sutadji, \& Rudiyanto, 2016). Software tersebut telah divalidasi oleh 2 ahli. Ahli yang pertama adalah ahli pemrograman yang menekuni penilaian pendidikan dari Fakultas Teknik Teknik UNY. Ahli yang kedua adalah ahli pemrograman dari Jurusan Pendidikan Elektronika, Fakultas Teknik UNY. Hasil penilaian kedua ahli tersebut menunjukkan bahwa untuk aspek kemudahan diakses berada pada kategori baik, sedangkan untuk aspek kebenaran proses berada pada kategori sangat baik. Selain memberikan penilaian mengenai kemudahan akses dan kebenaran proses, ahli juga memberikan masukan-masukan secara kualitatif. Masukanmasukan tersebut digunakan untuk perbaikan sistem rapor online yang telah dikembangkan. Setelah dilakukan perbaikan berdasarkan masukan ahli, selanjutnya dilakukan ujicoba skala luas yang melibatkan calon pengguna software.

Uji coba skala luas ini merupakan tahap implementasi dari pengembangan software yang dilakukan. Implementasi ini melibatkan calon pengguna yaitu tenaga pendidik dan teknisi teknologi informasi di SMK. Dengan demikian penelitian ini bertujuan untuk mendeskripsikan implementasi penulisan laporan hasil belajar siswa SMK pada pelaksanaan Kurikulum 2013 menggunakan software penulisan rapor online. Melalui tahap implementasi ini diharapkan diperoleh masukanmasukan dari calon pengguna untuk perbaikan 
software yang dikembangkan, sehingga dihasilkan software penulisan rapor online yang berkualitas dan siap digunakan khususnya pada SMK.

\section{METODE PENELITIAN}

Penelitian ini merupakan studi deskriptif eksploratif, yang merupakan bagian dari penelitian pengembangan dengan menggunakan model (Sharma, 2012). Penelitian ini menggunakan pendekatan kualitatif yang fokus untuk mendeskripsikan implementasi pemanfaatan software penulisan rapor online di SMK yang menggunakan Kurikulum 2013. Partisipan kegiatan pemanfaatan software penulisan rapor online di SMK sebanyak 9 SMK baik negeri dan swasta di Provinsi Daerah Istimewa Yogyakarta, yaitu SMKN 5 Yogyakarta, SMK PIRI Yogyakarta, SMK Muhammadiyah 1 Patuk, Gunung Kidul, SMK Muhammadiyah Sewon, SMKN 1 Wonosari, Gunung Kidul, SMK Seyegan Yogyakarta, SMK Diponegoro Yogyakarta, dan SMKN 1 Wates. Adapun partisipan dari masing-masing SMK tersebut melibatkan wakil kepala sekolah bagian kurikulum, guru kelas, dan teknisi teknologi informasi dari tiap sekolah

Data dikumpulkan dengan observasi dan angket. Observasi dilakukan untuk mengidentifikasi permasalahan tentang implementasi pemanfaatan software penulisan rapor online dan juga untuk mengetahui kesulitan partisipan dalam mengoperasikan software penulisan rapor online tersebut. Angket digunakan untuk mengetahui kualitas software penulisan rapor online berdasarkan penilaian partisipan setelah menggunakan software tersebut. Angket yang digunakan berupa angket semi tertutup yang terdiri dari 27 butir pernyataan dan merupakan penjabaran dari definisi kualitas produk. Data hasil angket dinalisis secara kuantitatif dan kualitatif. Analisis kurangtitatif digunakan untuk memperoleh kategori kualitas software yang dikembangkan, sedangkan analisis kualitatif digunakan untuk mendeskripsikan kualitas software berdasarkan respon partisipan pada setiap butir pernyataan angket.

\section{HASIL DAN PEMBAHASAN}

\section{Hasil Ujicoba Skala Luas}

Untuk menjamin kualitas sistem rapor online, maka produk masuk dalam proses validasi yang melibatkan calon pengguna, yaitu 16 pendidik dan teknisi IT dari 9 sekolah menengah kejuruan di Daerah Istimewa Yogyakarta. Ujicoba dilaksanakan pada bulan Agustus 2016. Pada penerapan ini, setiap sekolah yang menerapkan software penulisan rapor melibatkan komponen kepala/wakil kepala sekolah urusan kurikulum, guru mata pelajaran, dan pengelola teknologi informasi di sekolah masing-masing. Sebelum menerapkan software, dilakukan pelatihan terlebih dahulu.

Pelatihan dilaksanakan selama 1 hari, dengan materi penulisan rapor dan software penulisan rapor. Peserta juga diberikan hardcopy manual software penulisan rapor. Pelaksanaan pelaihan ini berjalan lancar dan sesuai harapan, dengan mengkondisikan jaringan internet yang kuat di ruang pelatihan. Bapak/ibu guru memeroleh pencerahan mengenai strategi penulisan rapor, termasuk praktik pelaksanaan penilaian di sekolah. Namun demikian, ada beberapa kendala yang ditemui dalam implementasi software penulisan rapor online ini.

Kendala menyusun laporan hasil belajar dengan software, dapat diklasifikasikan berdasarkan penggunanya dan sistemnya. Berdasarkan pengguna, bapak/ibu guru kesulitan dalam menyusun rapor karena selama melaksanakan Kurikulum 2013, pelaksanaan penulisan diserahkan kepada tim penulis rapor di sekolah masing-masing. Selama di sekolah, tugas bapak/ibu guru hanya melaksanakan pembelajaran dan melaksanakan penilaian, tidak sampai pada tahap menuliskan rapor. Dari sisi sistem, ada sedikit kendala masalah skala penilaian yang digunakan. Kendala tersebut berkaitan dengan dikeluarkannya peraturan menteri yang baru, yaitu Permendikbud No. 23 Tahun 2016 tentang Standar Penilaian, dimana ada sebagian sekolah yang telah melakukan penyesuaian dengan mengubah skala dari 1-4 menjadi 0-100 sebagaimana tertuang dalam Permendikbud baru tersebut, sedangkan disisi lain sebagian sekolah belum melakukan penyesuaian. Dua pilihan skala ini belum difasilitasi oleh sistem yang dikembangkan. 
Tabel 1. Kualitas Software yang Dikembangkan

\begin{tabular}{rcccc}
\hline \multicolumn{3}{c}{ Rentang Skor } & Kategori & Persentase \\
\hline 101,25 & $<\mathrm{X}$ & & Sangat Baik & $0 \%$ \\
78,75 & $<\mathrm{X} \leq 101,25$ & Baik & $56 \%$ \\
56,25 & $<\mathrm{X}$ & $\mathbf{7 8 , 7 5}$ & Sedang & $44 \%$ \\
33,75 & $<\mathrm{X} 56,25$ & Kurang Baik & $0 \%$ \\
& $\mathrm{X} \leq 33,75$ & Tidak Baik & $0 \%$ \\
\hline Rata-rata & & $\mathbf{7 8 , 1 2 5}$ & Sedang \\
\hline \multicolumn{7}{c}{ Sangat Baik } & $0 \%$ \\
Kesimpulan & & Baik & $75 \%$ \\
& & Cukup & $13 \%$ \\
& & Kurang Baik & $0 \%$ \\
Tidak menyimpulkan & Tidak Baik & $0 \%$ \\
\hline
\end{tabular}

Selanjutnya peserta ujicoba skala luas diberikan angket penilaian mengenai sistem yang dikembangkan. Penilaian terhadap sistem menggunakan angket semi tertutup. Pada angket ini, terdapat 27 butir penilaian dalam instrumen yang merupakan penjabaran dari definisi kualitas produk. Adapun data hasil penilaian disajikan pada Tabel 1 .

Butir pernyataan yang telah diisi oleh 16 guru dilakukan analisis sehingga tanggapan terhadap kualitas rapor online dapat terklasifikasi seperti pada tabel. Terdapat 9 guru atau 56\% dari keseluruhan responden menyatakan bahwa rapor memiliki kualitas baik, sedangkan sisanya yaitu 7 guru atau $44 \%$ menyatakan bahwa kualitas rapor masuk dalam kategori sedang. Ditinjau dari rata-rata dari keseluruhan penilaian tiap butir, kualitas rapor berada pada nilai 78,125 . Jika nilai tersebut disetarakan dengan rentang skor klasifikasi maka masuk dalam kategori sedang. Pada bagian terakhir dalam instrumen, guru diminta untuk menarik kesimpulan mengenai kualitas rapor. Terdapat $75 \%$ guru yang menyatakan sistem rapor online baik, $13 \%$ guru mengatakan cukup, dan sisanya $13 \%$ tidak memberikan kesimpulan. Untuk melakukan interpretasi lebih jauh sebagai dasar penyempurnaan produk maka dilakukan telaah data kualitatif berupa kritik, saran, dan masukan yang disampaikan guru dalam proses validasi.

Secara umum pengguna menyambut dengan antusias produk pengembangan berupa rapor online karena mempermudah kerja pada proses penulisan rapor. Secara administrasi, pengguna juga dimudahkan karena ada pilihan variasi output sehingga tidak perlu mengolah secara manual. Selain itu rapot online juga dapat menjadi pusat informasi data yang mudah diakses dimanapun dan kapanpun sehingga kerumitan transaksi data yang selama ini dialami oleh guru dapat teratasi dengan mudah. Namun, guru sebagai pengguna memberikan berbagai kritik dan saran agar rapor online dapat memberikan manfaat secara optimal. Adapun berbagai kritik dan saran tersebut sebagai berikut.

\section{Kesesuaian dengan Kurikulum (Permendik- bud No. 23 Tahun 2016)}

Kritik guru sebagian besar mengerucut pada sinkronisasi sistem rapor online dengan peraturan pemerintah yang terbaru. Pembuatan sistem rapor pada masa transisi kurikulum memberikan tantangan tersendiri. Hal tersebut terbukti dengan perubahan peraturan pemerintah ditengah pengembangan produk. Permendikbud tentang Kurikulum 2013 beberapa kali mengalami penyempurnaan, tentu dengan beberapa perubahan pada sistem penilaian. Perubahan yang mencolok adalah skala penilaian dan sistem penilaian sikap. Sistem rapor online masih menggunakan penilaian skala maksimum 4 sedangkan saat ini mengacu dari Permendikbud yang terbaru per tahun 2016 adalah penilaian dengan skala maksimum 100 . Berikutnya adalah mengenai penilaian sikap, rapor online menyesuaikan dengan peraturan pemerintah sebelumnya dimana semua guru memiliki kewajiban untuk melakukan penilaian pada aspek-aspek sikap tersebut, namun saat ini penilaian sikap spiritual (KI 1) dan sikap sosial (KI 2) dilakukan secara langsung oleh guru mata pelajaran agama dan budi 
pekerti (yaitu mata pelajaran PPKn dan Pendidikan Agama) sedangkan guru mata pelajaran lain menilai secara tidak langsung pada saat KBM maupun di luar KBM yang kemudian penilaian tersebut diserahkan kepada wali kelas sebagai bahan penyimpulan sikap pada KI 1 dan KI 2 sebagai nilai rapor. Menurut Desi Wulandari, untuk menjamin kebermanfaatan produk perlu adanya sinkronisasi pada setiap perubahan peraturan. Fitriya Isnawati mengatakan bahwa benturan dengan peraturan pemerintah terbaru membuat sistem sulit diterapkan di sekolah.

Sebaiknya ada pemeliharaan berkala terhadap sistem sebagai kontrol atau jaminan kerja sistem. Fungsi dari pemeliharaan yang pertama adalah untuk merespon perkembangan kurikulum yang begitu cepat. Menurut pengalaman beberapa tahun terakhir, sering sekali terjadi perubahan peraturan pemerintah yang tentunya berdampak pada sistem penilaian. Hal tersebutlah yang harus dapat direspon cepat oleh pengembang. Dengan demikian maka fungsi rapor online tidak hanya sebagai media bantu penilaian tapi juga menjadi sebuah sistem informasi perkembangan kurikulum khususnya penilaian. Akan sangat baik ketika sistem rapor online dapat menyediakan format dan informasi berdasar peraturan pemerintah terbaru sebelum peraturan tersebut tersosialisasi secara luas sehingga kebermanfaatannya sebagai media bantu guru dalam melakukan penilaian pun semakin maksimal.

\section{Kelengkapan Keterangan dalam Rapor}

Beberapa hal yang sebaiknya disempurnakan dalam pengembangan sistem rapor online adalah mengenai kelengkapan keterangan tambahan seperti status naik dan tidak naik kelas, catatan wali kelas, tanda tangan kepala sekolah, dan keterangan kelas. Keterangan naik kelas merupakan penegasan pencapaian hasil belajar siswa. Catatan wali kelas merupakan media komunikasi wali kelas dan orangt ua siswa. Selain itu catatan juga dapat dijadikan data sebagai bahan refleksi siswa untuk mengambil langkah dalam menempuh pendidikan di semester selanjutnya. Menurut Zainal (SMKN 5 Yogyakarta), keterangan tersebut sangat penting berkaitan dengan keterbacaan rapor. Keterangan kelas pada rapor memudahkan berbagai kalangan dalam membaca dan menerjemahkan isi rapor.
Ruang untuk tanda tangan kepala sekolah adalah jaminan legalitas rapor sebagai antisipasi agar tidak ada penyelewengan pada basis data tersebut. Keterangan tersebut merupakan keterangan primer yang seharusnya disediakan karena sangat penting.

\section{Software Pendukukung (Office 2010)}

Sistem rapor online memiliki keterbatasan yaitu hanya support dengan Microsoft Office 2010. Padahal kebanyakan guru pada saat ini masih menggunakan Microsoft Office 2007. Pihak pengguna dari SMK Muhammadiyah 1 Patuk dan SMK Negeri 2 Sewon mengeluhkan bahwa kondisi tersebut menimbulkan kendala karena kebanyakan guru merasa kesulitan jika harus update program Microsoft Office menjadi versi 2010. Bahkan ketika guru difasilitasi untuk melakukan update pun, guru belum tentu berkenan karena sudah merasa nyaman dengan software yang dipakai dan takut ketika software baru terinstal harus belajar ulang.

\section{Kerjasama dengan Dinas Pendidikan atau Instansi Terkait}

Untuk pengembangan yang lebih lanjut sebaiknya ada kerjasama dengan instansi terkait dalam rangka penerapan produk di sekolah. Keterlibatan dari instansi terkait seperti Dinas Pendidikan selaku pihak yang berwenang dalam memberikan otoritas dapat menghilangkan keraguan pengguna karena bagaimanapun juga sekolah selalu mengikuti dinamika sesuai instruksi pemerintah. Kerja sama dengan pemerintah dapat memberikan jalan untuk melakukan penerapan produk pada skala yang lebih luas.

\section{Pembatasan Wewenang Siswa}

Kemampuan siswa dalam mengelola akun menimbulkan kekhawatiran oleh guru. Dikhawatirkan siswa tidak dapat bertanggung jawab dan tidak mampu mengelolah akun dengan baik. Kemungkinan yang diharapkan adalah siswa dapat mengisi data secara benar, namun pada kenyataanya ada siswa yang cenderung tidak bertanggungjawab dengan melakukan pengisian data yang tidak sesuai atau siswa yang tidak mempedulikan himbauan sehingga data belum terisi dengan benar. Padahal data tersebut sangat penting digunakan untuk berbagai kepentingan akademik. Kondisi tersebut membuat guru harus 
selalu melakukan koreksi data siswa untuk memastikan kebenaran data. Dengan demikian maka sebaiknya siswa tidak diberikan wewenang untuk mengelola data diri dalam sistem rapor online. Wahyu $\mathrm{P}$ mengatakan bahwa sebaiknya admin atau wali kelas saja yang memiliki akses untuk mengelola data pribadi siswa.

\section{Operasi Relatif Rumit}

Terdapat beberapa hal yang dianggap kendala oleh pengguna. Secara ringkas pengguna menggolongkannya dalam sebuah kerumitan. Kerumitan pertama adalah menu login admin, guru, wali kelas, dan siswa terdapat dalam alamat web yang berbeda. Kondisi tersebut dianggap sebagai sebuah kerumitan karena ada beberapa guru yang memiliki rangkap peran harus berganti alamat web saat berubah peran. Kerumitan kedua adalah mengenai sistem input data. Siti Rahayu mengatakan bahwa pemanfaatan sistem rapor online relatif rumit, terutama pada proses input data. Ketiga adalah mengenai error messages. Suwarno menyampaikan bahwa tidak mendapati penjelasan terhadap kesalahan yang dilakukan saat muncul error messages. Kondisi tersebut membuat guru kebingungan dalam merunut kesalahan yang dilakukan sehingga akan banyak waktu yang terbuang. Padahal proses penulisan rapor membutuhkan waktu yang efektif dan efisien karena dilaksanakan dalam rentang waktu terbatas. Kendala tersebut terutama dialami oleh guru yang relatif senior. Guru senior relatif lama dan gugup dalam menghadapi teknologi baru. Transisi penerapan teknologi baru harus berjalan dengan cepat dan lancar sehingga tidak banyak waktu yang terbuang untuk memahami. Sebaiknya terdapat guide book dan pelatihan yang detail sehingga pengguna memiliki pemahaman yang baik terhadap sistem. Hal lain yang dapat dilakukan untuk mengatasi masalah tersebut adalah adanya wadah komunikasi dengan server atau pengembang melalui sistem online. Dengan demikian maka setiap kesulitan dapat langsung ditanyakan dan mendapat respon solusi yang tepat.

\section{Analisis Mendalam Mengenai Kualitas Produk}

Untuk melakukan kajian lebih mendalam mengenai kualitas produk pengembangan maka pengembang melakukan penye- lidikan pada setiap butir pernyataan dalam lembar validasi. Calon pengguna yang dilibatkan dalam proses validasi ini telah menggunakan dan menelusuri sistem secara menyeluruh mulai dari input sampai dengan output. Adapun data tersebut dirangkum pada Tabel 2.

Secara umum calon pengguna yang memberikan penilaian positif (setuju dan sangat setuju) terhadap masing-masing aspek terkait kualitas sistem penulisan sistem rapor online berada di atas angka $60 \%$. Hal ini menunjukkan bahwa sebagian besar calon pengguna dapat merasakan manfaat dari software penulisan rapor online ini. Hanya saja pada aspek-aspek tertentu seperti aspek nomor $1,2,5,12,16,17,18$, dan 25 masih terdapat cukup banyak calon pengguna yang memberikan respon negatif. Hal ini tentunya disinyalir disebabkan oleh beberapa faktor, baik itu yang bersifat teknis maupun non teknis.

Aspek pertama yang dicermati dalam proses validasi adalah aksesibilitas fitur dalam rapor online. Diharapkan calon pengguna dapat memanfaatkan semua fitur dengan baik. Namun dalam proses validasi ini belum sepenuhnya calon pengguna dapat dengan nyaman menggunakan setiap fitur dimana masih ada $38 \%$ yang menyatakan kurang setuju. Hal tersebut disinyalir karena responden masih belum dapat menggunakan semua fitur secara mudah. Begitupun dengan aspek kemudahan navigasi sistem rapor online (aspek 2) terdapat 53\% responden menyatakan kurang setuju dan $7 \%$ tidak setuju bahwa navigasi sistem rapor online mudah. Dengan kata lain, sebagian besar responden masih sering mengalami kebingungan mengenai navigasi sistem rapor online.

Pada aspek kelima yaitu berkaitan dengan fleksibilitas sistem berdasar spesifikasi komputer $25 \%$ responden menyatakan kurang setuju, dan $6 \%$ menyatakan tidak setuju. Hal ini menunjukkan bahwa masih ada sebagian responden yang ragu kalau sistem yang dikembangkan dapat berjalan pada segala spesifikasi komputer. Sedangkan untuk aspek kesesuaian fungsi fitur dengan harapan pengguna (aspek 12), hanya sedikit responden yang menyatakan setuju, sedangkan sisanya $56 \%$ menyatakan kurang setuju dan $6 \%$ tidak setuju. Situasi tersebut disinyalir karena calon pengguna kesulitan dalam menyesuaikan peskalaan nilai sesuai dengan Permendikbud terbaru. 
Tabel 2. Respon Calon Pengguna pada Setiap Aspek Validasi

\begin{tabular}{|c|c|c|c|c|c|}
\hline \multirow{3}{*}{ No. } & \multirow{3}{*}{ Aspek Validasi } & \multicolumn{4}{|c|}{ Persentase Respon Guru (\%) } \\
\hline & & Sangat & Setuju & Kurang & Tidak \\
\hline & & Setuju & & Setuju & Setuju \\
\hline 1. & Aksesibilitas fitur sistem rapor online & 6 & 56 & 38 & 0 \\
\hline 2. & Kemudahan navigasi sistem rapor online & 7 & 33 & 53 & 7 \\
\hline 3. & Akurasi hasil akhir operasi & 6 & 81 & 13 & 0 \\
\hline 4. & Keberfungsian dan efektivitas error messages & 12 & 75 & 13 & 0 \\
\hline 5. & Fleksibilitas sistem berdasarkan spesifikasi piranti & 25 & 44 & 25 & 6 \\
\hline 6. & Kebermanfaatan informasi kegagalan operasi & 12 & 75 & 13 & 0 \\
\hline 7. & Fleksibilitas waktu akses & 31 & 50 & 19 & 0 \\
\hline 8. & Kebermanfaatan fitur restart & 12 & 69 & 19 & 0 \\
\hline 9. & Sinkronisasi sistem dengan software lain & 31 & 69 & 0 & 0 \\
\hline 10. & Sistem tidak mudah crash pada saat input data & 6 & 75 & 19 & 0 \\
\hline 11. & Kejelasan manual penggunaan & 13 & 81 & 6 & 0 \\
\hline 12. & Kesesuaian fungsi fitur dengan harapan pengguna & 0 & 38 & 56 & 6 \\
\hline 13. & Fleksibilitas komponen hardware piranti & 13 & 69 & 19 & 0 \\
\hline 14. & $\begin{array}{l}\text { Kemampuan sistem dalam bertukar informasi dengan } \\
\text { aplikasi lain }\end{array}$ & 25 & 75 & 0 & 0 \\
\hline 15. & Estetika dan organisasi tampilan & 14 & 75 & 13 & 0 \\
\hline 16. & Kemudahan maintenance sistem & 0 & 75 & 25 & 0 \\
\hline 17. & Kemudahan pengoperasian & 0 & 75 & 25 & 0 \\
\hline 18. & Kualitas sistem rapor online secara keseluruhan & 0 & 63 & 38 & 0 \\
\hline & Fleksibilitas penggunaan sistem operasi & 12 & 75 & 13 & 0 \\
\hline & Konsistensi hasil input & 12 & 75 & 13 & 0 \\
\hline & Reliabilitas sistem rapor online & 0 & 87 & 13 & 0 \\
\hline & Keamanan data & 12 & 75 & 13 & 0 \\
\hline & Kemampuan mengakomodasi data & 0 & 81 & 19 & 0 \\
\hline & Efektivitas jumlah personil pengelolah dan waktu & 0 & 87 & 13 & 0 \\
\hline & Kemudahan penggunaan sistem rapor online & 0 & 75 & 25 & 0 \\
\hline & Keberfungsian pesan dan petunjuk dalam sistem & 13 & 87 & 0 & 0 \\
\hline 27. & Keselarasan dan kemenarikan tampilan antarmuka & 6 & 88 & 6 & 0 \\
\hline
\end{tabular}

Dalam hal kemudahan maintenance (aspek 16), 25\% responden mengatakan kurang setuju dengan anggapan bahwa sistem yang dikembangkan mudah dalam segi pemeliharaannya. Begitupun terkait pengoperasian sistem rapor online (aspek 17) juga masih terdapat $25 \%$ responden yang menyatakan kurang setuju bahwa pengoperasian rapor online relatif mudah. Hal ini disinyalir karena ketidakfamiliaran responden dengan sistem rapor berbasis online sehingga terjadi kegagapan dan mudah bingung dalam menghadapi langkah-langkah operasional sistem.

Berikutnya terkait data penilaian global sistem rapor online oleh para pengguna (aspek
18), dimana data penilaian tersebut sangat penting untuk menjaring informasi general kualitas produk pengembangan. Selain itu, data penilaian global juga dapat dijadikan sebagai bahan crosscheck dengan bagian detail lain yang divalidasi. Data yang tergambar pada gambar 18 menunjukan bahwa $62 \%$ calon pengguna mengatakan setuju bahwa kualitas rapor online secara keseluruhan sangat baik, sisanya 38\% mengatakan kurang setuju. Kelompok terakhir merupakan kelompok beranggotakan kumpulan calon pengguna yang mengalami kesulitan dalam pengoperasian dan kebingungan menentukan skala penilaian setelah terjadi perubahan peraturan 
menteri pendidikan dan kebudayaan khususnya mengenai standar penilaian.

Aspek berikutnya yang mendapatkan respon negatif dari calon pengguna adalah mengenai penilaian terhadap kemudahan penggunaan sistem rapor online (aspek 25). Pada dasarnya dikembangkannya sistem rapor online adalah untuk memfasilitasi pengguna sehingga pekerjaan mereka menjadi lebih mudah dan efisien. Oleh karena itu memberi perasaan mudah digunakan merupakan garansi yang diberikan pengembang kepada pengguna. Terdapat $75 \%$ calon pengguna yang merasa cukup mudah memahami dan menggunakan sistem rapor online, sisanya $25 \%$ ragu dalam menjawab sehingga kurang setuju. Dengan demikian maka pengembang harus menelusuri masalah yang dialami oleh $25 \%$ calon pengguna sehingga produk dapat dikembangkan hingga semua pengguna dapat mudah memahami dan menggunakan.

\section{Pembahasan}

Secara umum calon pengguna (wakil kepala sekolah, guru mata pelajaran, dan teknisi IT) menyambut antusias software penulisan rapor online yang dikembangkan, karena dapat mempermudah pekerjaan pendidik, khususnya guru mata pelajaran dalam hal menuliskan laporan hasil belajar siswa. Jika selama ini semenjak diberlakukannya Kurikulum 2013 guru-guru mengeluhkan banyaknya waktu mereka tersita untuk menuliskan laporan hasil belajar siswa, maka dengan hadirnya software penulisan rapor online ini menjadikan pekerjaan guru menjadi lebih efisien. Dengan kata lain hadirnya teknologi dalam bentuk software penulisan rapor online ini merupakan salah satu solusi untuk mengatasi permasalahan di bidang penilaian. Hal ini sesuai dengan pendapat ahli yaitu Pellegrino \& Quellmalz (2010) dan ClarkeMidura \& Dede (2010).

Terkait dengan kualitas software penulisan rapor online, sebagian besar calon pengguna menyimpulkan bahwa software memiliki kualitas baik. Hal ini menunjukkan bahwa sebagian besar calon pengguna mampu mengoperasikan sistem penulisan rapor online dengan baik. Keberhasilan tersebut tentunya tidak terlepas dari penggunaan bahasa pemrograman PHP dan MySQL dalam sistem yang dikembangkan. Bahasa pemrograman ini dikenal mampu menciptakan halaman web dinamis dengan hasil optimal serta dilengkapi dengan beberapa operasi seperti menghitung nilai total, rata-rata, maupun operasi matematis lainnya yang dibutuhkan dalam proses pelaporan hasil belajar. Dengan demikian penggunaan bahasa pemrograman yang tepat seperti PHP dan MySQL menjadi faktor kunci dalam keberhasilan sistem penulisan rapor online. Hal ini sesuai dengan pendapat ahli diantaranya Atkinson (2001); Bolboacă et al. (2003); Harris (2004); Bulger et al. (2004); Schlossnagle (2004); Valade (2008); Lerdorf et al. (2006); Gilmore (2008); Gosselin et al. (2011); dan Nixon (2015).

Selain hal tersebut, dalam implementasi pemanfaatan penulisan rapor online ini masih ditemui beberapa kendala seperti yang dikemukakan oleh beberapa calon pengguna. Secara umum kendala utama yang dihadapi oleh calon pengguna dalam pemanfaatan software penulisan rapor online ini terkait dengan perubahan peraturan pemerintah dalam menentukan skala penilaian. Adanya perubahan skala penilaian dari skala $1-4$, menjadi skala 0 -10 , bahkan dalam peraturan terbarunya pemerintah mengubah skala penilaian menjadi 0 - 100 menyebabkan calon pengguna kesulitan dalam memilih skala penilaian. Padahal ketika tahap implementasi ini, sistem penulisan rapor online masih mengikuti peraturan pemerintah yang lama yaitu menggunakan skala $1-4$. Hal ini tentunya makin membuat calon pengguna menjadi bingung. Terkait dengan hal tersebut, pemerintah hendaknya melakukan sosialiasi dan melibatkan para guru dalam melakukan perubahan kurikulum, khususnya terkait dengan standar penilaian. Hal ini sesuai dengan pendapat (Hameed, 2013).

Sesuai dengan tujuan awalnya bahwa pengembangan software penulisan rapor online ini adalah untuk mengatasi kesulitan guru dalam melakukan pelaporan hasil belajar siswa pada Kurikulum 2013 yang menganut prinsip penilaian autentik. Adanya prinsip penilaian autentik ini menjadikan beban guru bertambah dalam hal pelaksanaan penilaian, sehingga menimbulkan banyak keluhan. Berdasarkan pendapat sebagian besar calon pengguna hadirnya software ini sangat membantu mereka dalam menyusun laporan hasil belajar siswa. Hal ini sesuai dengan hasil penelitian (Sudiyanto et al., 2016), bahwa sistem rapor online dapat mempermudah penilaian dalam Kurikulum 2013. 
Meskipun disambut antusias oleh calon pengguna, software penulisan rapor online yang dikembangkan ini tetap memiliki beberapa kekurangan. Kekurangan yang paling menonjol adalah terkait skala nilai yang digunakan. Namun hal ini dapat diatasi dimana telah dilakukan penyesuaian skala penilaian sesuai dengan Permendikbud terbaru. Hal lainnya yang ditemui adalah masih adanya beberapa calon pengguna yang menganggap bahwa pengoperasian sistem cukup rumit. Hal ini disinyalir karena calon pengguna tersebut belum terbiasa dengan sistem berbasis komputer ini, karena selama ini penulisan rapor online hanya dilakukan secara manual. Namun demikian masukan-masukan lain dari calon pengguna tetap dijadikan pertimbangan untuk melakukan penyempurnaan software penulisan rapor online.

\section{SIMPULAN}

Secara umum calon pengguna menyambut dengan antusias software penulisan rapor online karena mempermudah kerja pada proses penulisan rapor. Secara administrasi, calon pengguna juga dimudahkan karena ada pilihan variasi output sehingga tidak perlu mengolah secara manual. Selain itu sistem rapor online juga dapat menjadi pusat informasi data yang mudah diakses dimanapun dan kapanpun sehingga kerumitan transaksi data yang selama ini dialami oleh guru dapat teratasi dengan mudah. Terkait kualitas software yang dikembangkan sebanyak $56 \%$ responden menyatakan bahwa software yang dikembangkan memiliki kualitas baik dan sisanya $44 \%$ responden menyatakan bahwa bahwa software yang dikembangkan memiliki kualitas sedang. Beberapa masukan responden untuk perbaikan software yaitu (1) perlu adanya sinkronisasi sistem dengan peraturan pemerintah terbaru (2) penyempurnaan kelengkapan keterangan dalam sistem; (3) perlu adanya kerjasama dengan dinas pendidikan atau instansi terkait; dan (4) pembatasan wewenang siswa. Berdasarkan masukan-masukan tersebut dilakukan perbaikan sehingga software siap digunakan untuk membantu guru SMK di Indonesia menyusun laporan hasil belajar menggunakan Kurikulum 2013.

Untuk penelitian lebih lanjut, perlu diteliti strategi guru di sekolah-sekolah menuliskan rapor. Hal ini akan mempermudah perbaikan dan pengembangan sistem. Demikian pula halnya dengan pengembangan software yang terus menerus perlu dilakukan. Perbaikan ini sangat berguna untuk perbaikan sistem dan juga mengantisipasi berubahnya peraturan pemerintah terkait dengan Kurikulum 2013.

\section{DAFTAR PUSTAKA}

Atkinson, L. (2001). Core PHP programming using PHP to build dynamic web sites. London: Prentice Hall.

Bolboacă, S., Jäntschi, L., \& Cadariu, A. (2003). PHP and MySQL web application based on tanner-whitehouse standard. Leonardo Electronic Journal of Practices and Technologies, 1(2), 3752.

Bulger, B., Greenspan, J., \& Wall, D. (2004). MySQL/PHP database applications. Indianapolis: Wiley Publishing.

Buzzetto-More, N. A., \& Alade, A. J. (2006). Best Practices in e-Assessment. Journal of Information Technology Education: Research, 5, 251-269. Retrieved from https://www.informingscience.org/Publi cations $/ 246$ ? Source $=\% 2$ FJournals $\% 2 \mathrm{FJI}$ TEResearch\%2FArticles\%3FVolume\%3 D0-0

Clarke-Midura, J., \& Dede, C. (2010). Assessment, Technology, and Change. Journal of Research on Technology in Education, 42(3), 309-328. https://doi.org/10.1080/15391523.2010.1 0782553

Gilmore, W. J. (2008). Beginning PHP and MySQL from Novice to professional. New York: Springer.

Gosselin, D., Kokoska, D., \& Eastebrooks, R. (2011). PHP programming with MySQL. Boston: Course Technology.

Gronlund, N. E., \& Linn, R. L. (1990). Measurement and evaluation in teaching (6th ed.). New York: Collier Macmillan Publishers.

Gulikers, J. T. M., Bastiaens, T. J., \& Kirschner, P. A. (2004). A fivedimensional framework for authentic assessment. Educational Technology 
Research and Development, 52(3), 67. https://doi.org/10.1007/BF02504676

Hameed, G. (2013). Teachers' views about curriculum change at primary level: A case study of an urban girls primary school. International Journal of Academic Research and Reflection, 1(2), 26-36.

Harris, A. (2004). PHP 5/MySQL programming for the absolute beginners. Boston: Thomson.

Heinrich, E., Milne, J., \& Moore, M. (2009). An investigation into e-tool use for formative assignment assessment- status and recommendations. Educational Technology \& Society, 12(4), 176-192.

Johnson, R. L., Penny, J. A., \& Gordon, B. (2009). Assesing performance assessment. New York: Guilford Press.

Kartowagiran, B., \& Jaedun, A. (2016). Model asesmen autentik untuk menilai hasil belajar siswa Sekolah Menengah Pertama (SMP): Implementasi Asesmen Autentik di SMP. Jurnal Penelitian Dan Evaluasi Pendidikan, 20(2), 131. https://doi.org/10.21831/pep.v20i2.1006 3

Kearney, J., Fletcher, M., \& Bartlett, B. (2002). Computer-based assessment: Its use and effects on student learning. In $\mathrm{H}$. M. M. Pavlova \& D. Roebuck (Eds.), Presented at the Learning in Technology Education: Challenges for the 21st Century. Park Royal: Gold Coast QLD.

Lerdorf, R., Tatroe, K., \& MacIntyre. (2006). Programming PHP. Beijing: O'reilly.

Lombardi, M. M. (2008). Making the grade: The role of assessment in authentic learning. Retrieved from http://www.net.eduhouse.org.

Mendikbud RI. Peraturan Menteri Pendidikan dan Kebudayaan Nomor 64 Tahun 2013 tentang Standar Isi (2013).

Mendikbud RI. Peraturan Menteri Pendidikan dan Kebudayaan Nomor 66 Tahun 2013 tentang Standar Penilaian (2013).

Mendikbud RI. Peraturan Menteri Pendidikan dan Kebudayaan Nomor 104 Tahun 2014 tentang Standar Penilaian (2014).
Mendikbud RI. Peraturan Menteri Pendidikan dan Kebudayaan Nomor 21 Tahun 2016 tentang Standar Isi (2016).

Mendikbud RI. Peraturan Menteri Pendidikan dan Kebudayaan Nomor 23 Tahun 2013 tentang Standar Penilaian (2016).

Mueller, J. (2005). The authentic assessment toolbox: Enhancing student learning through online faculty development. Journal of Online Learning and Teaching, 5(1).

Nicol, D. (2008). Technology-supported assessment: A review of research. Retrieved from http://www.reap.ac.uk/resources.html

Nitko, A. J., \& Brookhart, S. M. (2011). Educational Assessment of Students (6th ed.). New York: Pearson.

Nixon, R. (2015). Learning PHP, MySQL \& JavaScript with Jquery, CSS \& HTML. Sebastopol, CA: O'reilly.

Paszko, C., \& Turner, E. (2001). Laboratory information management systems. New York: Marcel Dekker, Inc.

Pellegrino, J. W., \& Quellmalz, E. S. (2010). Perspectives on the Integration of Technology and Assessment. Journal of Research on Technology in Education, 43(2),

119-134. https://doi.org/10.1080/15391523.2010.1 0782565

Rennert-Ariev, P. (2005). A theoretical model for the authentic assessment of teaching. Practical Assessment, Research \& Evaluation, 10. Retrieved from http://pareonline.net/getvn.asp?v=10\&n $=2$

Retnawati, H. (2015a). Hambatan guru matematika sekolah menengah pertama dalam menerapkan kurikulum baru. Cakrawala Pendidikan, XXXIV(3).

Retnawati, H. (2015b). The comparison of accuracy scores on the paper and pencil testing vs. somputer-based testing. The Turkish Online Journal of Educational Technology, 14(4), 135-142.

Retnawati, H., Hadi, S., \& Nugraha, A. C. (2016). Vocational high school teachers' difficulties in implementing the 
assessment in curriculum 2013 in yogyakarta province of indonesia. International Journal of Intructional, 9(1), 33-48. Retrieved from http://www.e-

iji.net/dosyalar/iji_2016_1_3.pdf

Reynold, C. R., Livingstone, R. B., \& Wilson, V. (2010). Measuremet and assessment in education. New York: Pearson.

Rudner, L. M., Garcia, V., \& Welch, C. (2006). An evaluation of IntelliMetric ${ }^{\mathrm{TM}}$ essay scoring system. Journal of Technology, Learning and Assessment, 4(4). Retrieved from http://ejournals.bc.edu/ojs/index.php/jtla/ article/view/1651

Rukmana, T., \& Mundilarto, M. (2016). Keterlaksanaan penilaian autentik mata pelajaran fisika SMA negeri. Jurnal Inovasi Pendidikan IPA, 2(1), 111. https://doi.org/10.21831/jipi.v2i1.8382

Schlossnagle, G. (2004). Advanced PHP programming: A practical guide to developing large-scale websites and application with PHP 5. Indianapolis: Sams Publishing.

Sharma, G. (2012). Software engineering notes. Retrieved November 20, 2012, from http://guideforengineers.com/

Singleton, C. (2001). Computer-based assessment in education. Educational and Child Psychology, 18(3), 58-74.

Solichin, A. (2013). Pemrograman web dengan PHP dan MySQL. Retrieved from http://achmatim.net

Sudiyanto, G., Sutadji, E., \& Rudiyanto, E. (2016). Implementasi penilaian autentik kurikulum 2013 pada rapor online di SMK Negeri 6 Malang. Jurnal Dinamika, 1(1), 51-56.

Taylor, A. . (2010). SQL for dummies. Indianapolis: Willey Publishing Co.

Valade, J. (2008). PHP \& MySQL web development all in one desk reference for dummies. Hoboken: Willey Publishing.

Waycott, J., Gray, K., Clerehan, R., Hamilton, M., Richardson, J., Sheard, J., \& Thompson, C. (2010). Implications for academic integrity of using web 2.0 for teaching, learning and assessment in higher education. International Journal for Educational Integrity, 6(2), 8-18. Retrieved from http://www.ojs.unisa.edu.au/index.php/IJ EI/article/view/699/527

Widigdo, A. K. (2003). Tutorial "dasar pemrograman PHP MySQL.” Kuliah Umum Ilmu Komputer.Com. 